\title{
Language Teaching Profile of Curriculum 2013 in Bengkulu City
}

\author{
Arono \\ University of Bengkulu \\ Bengkulu, Indonesia \\ arono@unib.ac.id
}

\begin{abstract}
The 2013 curriculum is revised in accordance with the needs and development of science including language teaching. The purpose of this study was to describe the assessment of teaching materials, lexical density, and scientific implementation. This research applied descriptive method. Data of this research was collected by using questionnaires, text analysis, tabulation, and conclusion The results showed that the content, presentation, language, and Fig. aspects of the three textbooks had good categories and was suitable to apply. However, the content feasibility aspect, there was one book had enough category, was English published by Yrama Widya. The lexical density of the Kemendikbud textbook found that the text level did not match the expected lexical density index. The implementation of the scientific approach reached an average of 3.13 (52\% very good and $43 \%$ good) with a good category.
\end{abstract}

Keywords-language teaching profile; Curriculum 2013; textbook; lexical density; scientific approach.

\section{INTRODUCTION}

The curriculum is a set of planning and organization of aim, content, and learning the material as the guide to learning activity to achieve a particular educational objective. Nowadays, Curriculum 2013 for senior high school in Indonesian had been implemented from grade $\mathrm{X}$ or first year of senior high school. Related to this explanation, there are several changes in some parts of education. Ref. [1] shows curriculum changes involve many different kinds such as content, methods, and assessment in learning teaching process. Based on the explanation above, the curriculum may affect teachers' pedagogical values and beliefs, teachers' understanding of the nature of language or second language learning, or their classroom practices and the use of teaching and learning materials. Among several changes in education parts teaching material also need to be adjusted because it is one of the most important factors in teaching and learning process. This argument is supported by [1] that teaching materials are regarded as a key factor in most language programs.

A textbook means a created material designed as materials for teaching-learning process in order to increase learners' knowledge and experience. Ref. [2] shows stated that the textbook is best seen as a source in achieving aims and objectives that have already been set in terms of learners needs. The textbook also can be defined as a book prepared for students in the teaching-learning process. It is used as a main component to deliver the material framework designed in the curriculum. They may deliver the foundation for the content of the lessons, the balance of skills taught and the types of language practice which the students take part in.

In consideration of the widespread use of curriculum 2013, English textbooks as new textbook have an essential role as the main access to learners in facilitating language learning. Therefore, this textbook will be the main object of analysis. From the policy perspective, the urgency to assess this textbook is also coming from the resistance of many teachers towards the quality of the books. As one of the facilitators of curriculum 2013 in 2014 period, the author encounters many critiques and said that this book has a lower quality in comparison with textbook published by the private publishing or previous KTSP English textbook. This has increased the currency of the issues, especially to assess the quality of the books and objectively compare the textbook.

Scientific Approach has been known in KTSP Curriculum in 2007/2008 where particularly this learning focuses on learners. The changes in 2013 curriculum focus on four standardization consisted of graduation competency, process, content, and assessment. This new curriculum was taken from the old curriculum that basically focuses on learning process just fulfills the target of student's knowledge. In 2013 curriculum, the learner seeks the knowledge not receive it. This approach has the same purpose with the approach of skill process. The balances of between hard skill and soft skill are the key from this curriculum. In fact, the problem of approach is not the curriculum problem but the implementation isn't to run well. It can be the scientific approach in 2013 curriculum will face the same problem if the teacher doesn't understand how to implement this approach in class. The process of scientific approach consists of observing, questioning, collecting information/experimenting, associating and communicating phases, the materials are developed by the teachers and the teachers also do assessment the learning process and product in implemented the scientific approach in class.

Teachers had many inspirations about how to implement the new approach to the learning and teaching process. The English teacher admitted after following some inquiry activities. She falls back to the lecture based on the student's confusion that is caused that commonly the teacher's teaching based on the existing materials where the students accustomed to just receive the knowledge without having some effort to get the knowledge and solve the learning problem by themselves. To change this paradigm the appropriate way that 
teacher do was how to make the teaching and learning process have meaningful. It means that teacher can teach such a way to make the students take a part in this process. However, in reality, there are many things that teacher still doesn't understand relate to 2013 curriculum. The first is compilable in assessment. The teacher still confused how to assess in this curriculum; the second one was how to implement the scientific approach in teaching learning process in class, and the last one is how to make the students active. It is caused by the teacher still didn't understand how to motivate the students in the scientific process in learning. The teacher had noticed that the confusion of students in facing the new style in teaching and learning process.

Based on the information above, textbook condition, lexical density, and implementation of scientific approach in teaching were some of the teaching language profiles in senior high school in Bengkulu city. This research described some components which represented language teaching profile in the curriculum 2013 in Bengkulu city. This profile means a representation of a writer into language teaching of curriculum 2013 viewed from analysis and evaluation of textbooks used, lexical density used in textbooks, and teachers' competence in identifying problems in language teaching in Bengkulu as well as a new policy in language teaching.

\section{METHOD}

This research applied meta-analysis approach with the quantitative descriptive method. This research conducted meta-analysis JOALL [3], [4], [5], [6]. Textbooks on the lexical aspect used are English high school textbooks, while the scientific implementation at senior high school (Class X) and junior high school (Class VII) level where applying curriculum 2013. The teaching materials assessed were teaching materials from Kemendikbud, Yrama Widya, and Erlangga in Class $X$. This research was undertaken from textbooks and phenomena in language learning [7], [8]. The qualitative data was quantified in percentage form. The technique of data collection conducted questionnaire, text analysis, tabulation, and concluding.

\section{RESULTS \& DISCUSSION}

Analysis of English textbooks for High School Class X involves three assessors. They are two English teachers senior high school 4 Bengkulu as co- rater 1 and co- rater 2 and the researcher himself. This research was conducted by analyzing English language textbooks based on content aspects, presentation, language use, and graphic by BSNP. The score had correlated from inter-rater. The score was correlated when the score from the raters is in the same category or interval. In this research, reliability inter-rater is illustrated in Table I.

TABLE I. SUMMARY CALCULATION OF PERCENT AGREEMENT BETWEEN RATERS [3]

\begin{tabular}{|c|c|c|c|}
\hline $\begin{array}{c}\text { English } \\
\text { Textbooks }\end{array}$ & $\begin{array}{c}\text { \% } \\
\text { Agreement }\end{array}$ & $\begin{array}{c}\text { Level of } \\
\text { Agreement }\end{array}$ & \% of Reliable \\
\hline Textbook 1 & $86.85 \%$ & Strong & Almost Perfect \\
\hline Textbook 2 & $85.93 \%$ & Strong & Almost Perfect \\
\hline Textbook 3 & $91.24 \%$ & Almost Perfect & Almost Perfect \\
\hline AVERAGE & $88.00 \%$ & Strong & Almost Perfect \\
\hline
\end{tabular}

The language used in the instructions, explanations, or texts is very scientific and unfamiliar for the tenth graders and was not facilitated explicitly with a glossary of unfamiliar words. Thus, it was not relevant to learners' cognitive development. The language also was not relevant to learners' socio-emotional development, because most of the topics are scientific and therefore too demanding for learners. Pathway to English lacks in terms of language content because there was not enough explanation and practice for vocabulary comprehension. The lack of vocabulary lessons was a huge problem considering that this textbook has a lot of scientific and unfamiliar words. On the other hand, the texts contained many scientific words which were hard for learners to comprehend.

In this textbook, the message presented in each unit was clear and easily understood by learners. This was because of the grammar and vocabulary explanation brief and used familiar language. In addition, the topics chosen for each unit are learners' daily life and are appealing for them. Then, learners would find it easy to understand the message within the texts. The materials presented on coherence, show unity and sequenced from easy to complex.

Next, the result of these three textbooks indicated good category in graphic aspect. It was verified textbook 1 indicated very good category, textbook 2 and textbook 3 indicated the good category. Ref. [9] shows stated that graphic note in the textbook is: a) the size of the book; b) the design of book cover (appeal, typography, and illustration); c) the design of contents book; d) illustration (type, attractiveness, anatomy); e) the suitability of the paper. The textbook must be interesting and attractive toward the learners. Thus, they will be interested in using a textbook [10]. Based on the explanation above, a good textbook had the content matter and need to be more physical. The appearances of the content without good arrangement made the students were not interested to read it, and without good content, the students would not understand the content of the book. It is interesting for the students to have good physical, cover, illustration, and appearance of each chapter, as well as the color, and fonts.

Inter-rater correlation analysis result shown the average in textbook 1 was $(86.85 \%)$, indicating strong agreement and almost perfect reliability. The average in textbook 2 was (85.93\%), indicating strong agreement and almost perfect reliability. The average in textbook 3 was $(91.24 \%)$, indicating almost perfect agreement and almost perfectly reliability. Total percent of agreement between three raters was $(88.00 \%)$, indicating the level of agreement of inter- raters is strong and reliable of inter- raters is almost perfect.

TABLE II. THE AVERAGE OF TOTAL NUMBER OF WORDS AND LEXICAL DENSITY [4]

\begin{tabular}{|l|l|l|}
\hline Class & Total Number of Words & Lexical Density \\
\hline X & 412,75 & $51,91 \%$ \\
\hline XI & 794,11 & $50,57 \%$ \\
\hline XII & 269,94 & $51,77 \%$ \\
\hline
\end{tabular}

From Table II above, the highest average of a total number of words was in class XI, 798.11. And the lowest was in class 
XII, 269.94. The highest average of lexical density was in class X, 51.91\%. And the lowest was in class XI, 50.57\%.

Further, when we measured the percentage of the highest lexical density and the percentage of the lowest lexical density can be seen below.

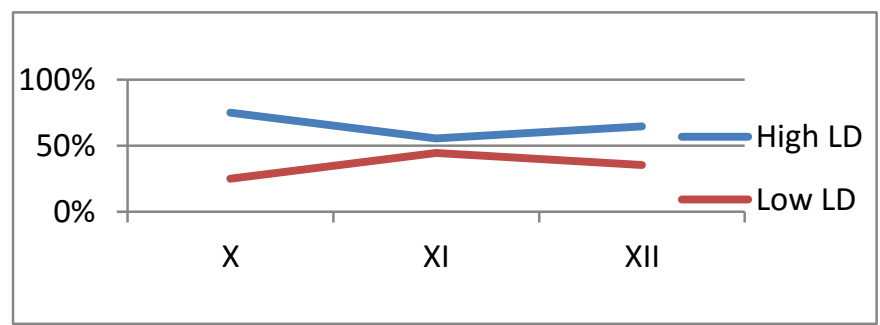

Fig. 1. The Percentage of The Highest Lexical Density and The Percentage of The Lowest Lexical Density [4]

It can be seen that the percentage of the highest lexical density is concentrated in class X. 75 percent of the text in class $\mathrm{X}$ has high lexical density, followed by class XII with 64.70 percent and class XI with 55.55 percent. Similarly, class $\mathrm{XI}$ has the highest percentage of lowest lexical density with 44.44 percent, followed by class XII with 35.30 percent and class X with 25 percent.

This study examined and assessed the quality of selected reading materials provided in the curriculum 2013 English textbooks for Senior High School provided by the Minister of Education of Indonesia. Hence, this research attempted to answer two major questions: To find out the lexical density that presented in reading passages of English textbooks; and to compare between levels (class X, class XI, and class XII) in order to find changes on how the lexical density index increase in accordance with the set difficulty level of texts between levels. A qualitative study was employed using a descriptive evaluative content analysis as its tools. The research applied lexical density as its main guiding theory with the classification of grammatical and lexical items formulated by [11]. The lexical density analysis was seen as important to shed the light on whether the reading material is accessible for students.

The observation was conducted by the researchers in the implementation of Scientific Learning Approach area used by the teacher in the classroom. In these steps, there are five phases in implementing this approach namely: Observing, Questioning, Exploring, Associating and Communicating phase. In each phase consists of some criteria's that are expected to be conducted by the teachers. The observation was done in two meetings. The total participants were three teachers. This section would be discussed in three parts. The first was the steps of scientific learning approach in a. Observing Phase b. Questioning Phase c. Exploring Phase. d. Associating Phase e. Communicating Phase. The second step was the materials which were developed by the teacher to support the implementation scientific learning approach in class. And the third one was the teachers assess the learning process in implementing scientific learning approach in class.
TABLE III. RESULT FOR IMPLEMENTATION OF SCIENTIFIC LEARNING APPROACH [5]

\begin{tabular}{|l|c|c|}
\hline \multicolumn{1}{|c|}{ Step in Scientific Approach } & Average & Categories \\
\hline Observing & 2.80 & Fair \\
\hline Questioning & 3.15 & Good \\
\hline Exploring & 3.18 & Good \\
\hline Associating & 3.47 & Very Good \\
\hline Communicating & 3.06 & Good \\
\hline Average & $\mathbf{3 . 1 3}$ & Good \\
\hline
\end{tabular}

Based on the distribution of the English language teachers who have implemented the Curriculum 2013, especially in Class VII junior high school 1 Bengkulu, junior high school 2 Bengkulu, junior high school 3 Bengkulu, and junior high school 4 Bengkulu, there were 8 teachers totally with details of each school were 2 teachers. The instrument comprised of lesson planning, learning implementation, and assessment of learning outcomes. This can be seen from the tabulation below.

TABLE IV. IMPLEMENTATION OF CURRICULUM 2013 AT JUNIOR HIGH SCHOOL BENGKULU CITY [6]

\begin{tabular}{|c|c|c|c|c|c|c|}
\hline \multirow[t]{2}{*}{ No. } & \multirow[t]{2}{*}{ Aspect } & \multicolumn{4}{|c|}{ Category } & \multirow{2}{*}{$\begin{array}{c}\text { Total of } \\
\text { Percentage }\end{array}$} \\
\hline & & $\begin{array}{l}\text { Very } \\
\text { Good } \\
\end{array}$ & Good & Enough & Less & \\
\hline $\mathrm{A}$ & $\begin{array}{l}\text { Lesson } \\
\text { Planning }\end{array}$ & $53 \%$ & $38 \%$ & $9 \%$ & 0 & $100 \%$ \\
\hline B & $\begin{array}{l}\text { Learning } \\
\text { Implementa } \\
\text { tion }\end{array}$ & $48 \%$ & $50 \%$ & $2 \%$ & 0 & $100 \%$ \\
\hline $\mathrm{C}$ & $\begin{array}{l}\text { Assessment } \\
\text { of learning } \\
\text { outcomes }\end{array}$ & $56 \%$ & $40 \%$ & $3 \%$ & 0 & $100 \%$ \\
\hline & Amount & $52 \%$ & $43 \%$ & $5 \%$ & 0 & $100 \%$ \\
\hline
\end{tabular}

Based on the table above, it can be explained that in general, the implementation of Curriculum 2013 at SMPN Bengkulu especially class VII is at good category at (52\%). It is based on the provision that $76 \%$ to $100 \%$ is a very good category, $51 \%$ to $75 \%$ is a good category, $26 \%$ to $50 \%$ is enough category, and $10 \%$ to $25 \%$ is less category. In the part of lesson planning aspect, it is a very good category at $53 \%$, $38 \%$ is in a good category, and $9 \%$ is at less category. Meanwhile, learning Implementation aspect is $48 \%$ of the very good category, $50 \%$ is in a good category, and $2 \%$ is at fewer categories. Then in the assessment of learning outcomes aspect, in general, teachers have been fully implemented curriculum 2013 with percentage $56 \%$ at the very good category, $40 \%$ of a good category, and $5 \%$ at fewer categories. Based on the table it could be argued that the implementation of learning needs an attention and an increase in intensity and in quality because through the implementation of learning it will be developed and assessed aspects of students' attitudes, knowledge, and skills. It means that the implementation of learning activities is mostly a reflection of the implementation of the curriculum in viewing learning process [12]. 


\section{CONCLUSION}

One aspect that can be improved curriculum 2013 is English textbook. Based on the results of research and discussion, it can be concluded that in terms of contents aspect based on the textbook evaluation devised BNSP that textbooks 1 and textbook 3 were at good textbooks. Then, Due to the presentation aspect based on the textbook evaluation devised BNSP, textbook 3 got a very good category whereas Textbook 1 and textbook 2 were in a good category. Regarding to language aspect textbook evaluation devised by BNSP, textbook 3 shown at very good category while Textbook 1 and textbook 2 were in a good category. Next, the graphics aspect based textbook evaluation devised by BNSP showed textbooks 1 and textbook 3 had very good category and textbook 2 was in a good category. Overall, it can be concluded that higher levels of texts do not necessarily guarantee higher lexical density indexes, and the levels of texts analyzed in this study did not match the expected indexes of lexical density as illustrated in the Fig. above.

The majority of the teachers who implemented the Scientific learning Approach were in observing, questioning, exploring, associating and communicating phases, but some teacher's performance still lacks implementing some phases and criteria especially in observing phase through watching the video and observing voice recording. Actually, in Scientific Learning Approach, the students are hoped more active and creative to add their horizon of thinking in order to get the knowledge. Almost most of the teachers implemented the learning material well. The teacher improved the learning material based on the syllabus and basic competence relate to the curriculum. Basically, the principle of choosing learning material was fulfilled consisting of relevance, principle, consistency, and term of references. The authentic assessment has been done by the teachers in the learning process. In this case, the authentic assessment requires learners not only to answer the test correctly but also to apply their knowledge, skill, and attitude to solve their problems of everyday life or real-life context.

\section{REFERENCES}

[1] Richard, Jack. 2001. Curriculum development in language teaching. USA Cambridge university press.

[2] Cunningsworth, A. 1995. Choosing Your Course Book. New York: Macmillan.

[3] Safrina, Emelda, Azwandi, and Arono, 2017. "Features of English Textbooks for the First - Year of Senior High School Implementing the 2013 - Curriculum” JOALL, MPBING FKIP Unib, Vol. 3 No. 1.

[4] Sari, Dian, Safnil, and Arono. 2016. "Measing Quality of Reading Materials in English Textbook: The use of Lexical Density Method in Assessing Complexity of Reading Materials of Indonesia's Curriculum13 (K13) Eglish Texbook". JOALL, MPBING FKIP Unib, Vol. 2 No. 2.

[5] Wifaqi, Hikma, Azwandi, and Arono. 2017. "The Implementation of Scientific Learning Approach at 10th Grade English Classes of Senior High School 4 Bengkulu City". JOALL, MPBING FKIP Unib, Vol. 3 No. 1 .

[6] Arono, Safnil, and Azwandi. 2016. "Kompetensi Guru Bahasa Inggris SMPN Kota Bengkulu dalam Mengimplementasikan Kurikulum 2013". Laporan Penelitian MPBING FKIP Unib.

[7] Mardalis. 1995. Metode Penelitian suatu Pendekatan Proposal. Jakarta: Sinar Grafika Offset.

[8] Muhadjir, Neong. 1996. Metode Penelitian Kualitatif. Yogyakarta: Rake Sarasin

[9] Muslich, M. 2010. Text Book Writing: Dasar- dasar Pemahaman, Penulisan dan Pemakaian Buku Teks. Yogyakarta: Ar- Ruzz Media

[10] Ure, J. (1971), Lexical density and register differentiation. In G. Perren and J.L.M. Trim (eds), Applications of Linguistics, London: Cambridge University Press. 443-452.

[11] Castello, E. 2008. "Text Complexity and Reading Comprehension Tests Reading Notes". http://adrien.barbaresi.eu/blog/e-castello-textcomplexity-and-reading-comprehension-tests-reading-notes.html. Bengkulu, 25 Mei 2016.

[12] Daryanto. 2014. Pendekatan Pembelajaran Saintifik Kurikulum 2013 Gava Media: Yogyakarta. 